\title{
IDENTITÁS-JELLEMZŐK A DÉL-ALFÖLDI RÉGIÓBAN
}

\author{
(Characteristics of Identity in the Southern Great Plain)
}

"A régiót nem csak a tér teszi, hanem az ido, a történelem"

(Bois 1971)

\section{MURÁNYI ISTVÁN - SZOBOSZLAI ZSOLT}

\section{Bevezetés}

Az identitás problémakörének előtérbe kerülését az elmúlt években Magyarországon több tanulmánykötet és monográfia megjelenése bizonyítja (Csepeli 1992; Erös 1996). A különböző társadalomtudományi diszciplínák fokozott érdeklődésében feltehetően annak is szerepe van, hogy a rendszerváltozást követően megváltozott az egyének viszonya az identitást konstituáló kontextusokhoz: a társadalmi szerepek nyilvánosan választhatóvá váltak, az identitás többnyire egyéni döntések függvénye lett (Dessewffy 1996).

Természetesen nem lehet eltekinteni a közvetlen társadalomtörténeti elözményektől, mivel a kilencvenes éveket megelözö évtizedekben a hatalmi-politikai elvárásoktól eltérỏ identitásmodellek (nemzeti, etnikai, politikai, vallási, szociokulturális stb.) nem jelentek (nem jelenhettek) meg nyilvános diskurzusokban. Társadalomlélektani szempontból fontos következményekkel járt, hogy az 1947 után uralkodó szocialista ideológia és annak társadalmi gyakorlata képtelen volt feldolgozni a két világháborút követő traumákat, s ezt csak erősitette az államszocialista korszakot megelőző hagyományos közösségek felbomlása, illetve a torz internacionalizmus jegyében elhallgatott bizonytalan magyarságtudat (Hankiss 1983). Mindezek következménye, hogy a kilencvenes évek elején a magyar társadalom többsége nem rendelkezett olyan identitásmintákkal, amelyek megfeleltek volna az alapjaiban és folyamatosan változó társadalmi környezet elvárásainak. A leginkább szociológiai és szociálpszichológiai kutatások - korábban és a kilencvenes években is - elsösorban a nemzeti identitás jellemzöinek feltárására vállalkoztak (Csepeli 1982; 1992; Lázár 1996; Szabó-Örkény 1998).

Az identitást a nemzeti csoport-hovatartozás dimenziójára „leszűkitő” empirikus társadalomtudományi gyakorlat kialakulásához vélhetően az államszocializmus másik lényeges társadalomlélektani sajátossága is hozzájárult: az egypártrendszer keretei között - szemben például a vallási vagy a „deviánsnak” tekintett, elkülönülő lokális kötődésủ csoportalakzatokkal - a nemzet politikai vállalás nélkül lehetett vonatkozási keret. 
A történeti-földrajzi kötődések alapján szerveződő identitás szociológiai vagy társadalomföldrajzi tárgyalására csak elvétve találunk példát a hazai szakirodalomban (Böhm-Pál 1987; Enyedi 1991; Csatári 1999). A szociológia nemzetközi szakirodalmában is csak néhány tanulmány foglalkozik a regionális identitás problémakörével. A közelmúlt irodalma elsősorban vagy a nacionalizmus és a nemzeti identitás területi elemzésével, a nemzetállami keretek gyengülése, a regionális autonómia - Quebec, Katalónia, Skócia - megerősödése nyomán létrejövő többszörös identitás elemeinek vizsgálatával foglalkozott (Hargreaves 1998), vagy az etnikai identitás problémáját helyezte elötérbe - a Zulu etnikum kialakulása a dél-afrikai KwaZulu-Natal tartományban - (Muthien-Khosa 1998). A megközelítések egy része túl általános - létezhetnek-e még egyáltalán közösségi társulások a modern társadalmakban - kontextusban foglalkozott az identitással (Robbins 1999). A konkrét empirikus kutatások középpontjában sem a regionális identitás elemeinek feltárása, hanem olyan problémák lokális szempontú megítélése szerepelt, mint az európai integráció kérdése (Diez-Medrano 1999). A kevés számú elméleti igénnyel fellépő írás közül kiemelkedik a Weakliem-Biggert szerzőpáros tanulmánya (1999), amely a politikai véleményekben jelentkező regionális eltérések sajátosságait elemzi az Egyesült Államokban 1992 és 1996 közötti adatfelvételek (General Social Surveys) alapján. A régiók közötti különbségek vizsgálatának két szempontját különítik el: az egyik a régión belüli szociális és gazdasági kapcsolatokra helyezi a hangsúlyt, míg a másik megközelítés szerint a regionális identitást más identitás konstrukciókkal (etnikai, vallási identitás) kell együtt vizsgálni (Weakliem-Biggert 1999). Nagyon izgalmasak azok az írások is, amelyek etnikai és vallási szempontból olyan érdekes országok regionális identitásával foglalkoznak, mint India. Részletesen olvashatunk arról, hogy milyen sokszínủ és többrétegü a regionális és vallási identitás az indiai társadalomban, miért értelmetlen amellett érvelni, hogy a piacgazdaság homogenizálja a kulturális különbségeket, vagy miért felesleges energia a különböző nyelvi közösségek politikai vitáit elemezni, csak a regionális identitás konceptualizálása hiányzik (Swarup 1997).

Mivel a lokális identitás fogalmának pontos értelmezése, illetve konceptualizálása nélkül maga a jelenség sem vizsgálható, ezért a következőkben erre teszünk kísérletet.

A lokális identitás fogalma konceptualizálásának releváns kiindulópontja a személyes és a társadalmi identitás fogalma lehet. A szocializálódó egyén és a társadalom közötti pszichikus kapcsolat az én (én-rendszer)hez kapcsolódó személyes (perszonális) identitás és a társadalmi identitás segítségével, illetve ezek kialakulásával írható le. A személyes azonosság tudata egyrészt a létezés folyamatosságának és azonosságának a szubjektív megélését (azonos vagyok önmagammal), másrészt valamely külső tényezővel (eszme, nem, generáció, etnikum vagy nemzet) való azonosságot jelenti. A társadalmi azonosságtudat ,az én-nek nevezett hipotetikus konstrukció sajátos alrendszere, aspektusa", mivel a társadalom kategoriális viszonyainak szelektív interiorizációja, az önmeghatározás és a személyes folytonosság képzetének alapja és társadalmi kerete (Pataki 1982). Az önmeghatározó kategóriák elfo- 
gadásának folyamata, azaz a társadalmi identitás kialakulása, a folyamatosan táguló környezettel (kiscsoportok és közösségek) való azonosulást jelenti. Ezt az azonosulási folyamatot egyszerre jellemzi az időközben megszủnő vagy új csoporttagságot jelentő változatosság és az egyéni pszichikum fejlődését befolyásoló társadalmi hatások kettőssége.

Mivel a nemzeti identitáshoz hasonlóan a lokális identitás fogalmát is a csoporthovatartozáson keresztül értelmezhetjük, megközelítésünk alapja a nemzeti identitás számunkra releváns definíciója (Csepeli 1982). A sokféle identitás-értelmezés közül fontosnak tartjuk megemlíteni a kisebbségi identitás történeti és regionális összefüggéseit elsősorban politológiai megközelítésben tárgyaló - igen bőséges hazai és külföldi irodalomra támaszkodó - A. Gergely András meghatározását: ,... az identitást egyszerủen mint vonatkoztatási rendszert kezelem, amely társadalmi tárgyakra, csoportjelenségekre és társadalmi térre kiterjedỏ személyiség-szférát jelent számomra, egyben az 'én' és 'ôk', illetve 'mi' és 'mások' konfliktusainak redukált, átélt és társadalomtörténetileg örökített mintáját" (A. Gergely 1996).

A lokális identitást a társadalmi identitástudat szerves részeként értelmezzük, melynek alapján az egyén a perszonális kapcsolathálónál (network) tágabb, földrajzi kategóriákkal meghatározható társadalmi csoport tagjának érzi és vallja magát. Az operacionalizálás során lényeges szempont, hogy milyen kategorizációt (lakóhely, kistérség, megye, régió) alapoz meg a csoport kijelölése, de ez nem jelenti a térbeli meghatározottság kizárólagosságát. A lokális identitás alapjának éppen azt tartjuk, hogy milyen érzelmi és kognitív jegyek alapján történik az adott kategorizációval leírt csoporthoz tartozás. Ezért a lokális vagy térségi csoporthoz tartozás egyúttal a csoport hagyományaival, értékrendjével való azonosság tudatát is jelenti. A nemzeti identitáshoz hasonlóan, a lokális identitás is elsősorban a hovatartozással és az azonosulással kapcsolatos érzelmi és gondolati mintákat tartalmazó kommunikációs együttes, szocializációs fejlemény, diakron és szinkron kommunikáció eredménye, melyet társadalmi-történeti tényezök generálnak és formálnak. A nemzeti identitás fenomenológiai értelmezése során Csepeli György (1992) elkülöníti a spontán vagy természetes és az ideológiai vagy tudatos nemzeti identitást. Feltehetően a lokális identitás két hasonló típusa is eltérỏen jellemzi a szociológiai értelemben különbözö társadalmi csoportokat. Az érzelmi jellegủ, a mindennapok során folyamatosan felmerüló önmeghatározás természetességét elősegítő és a korai életszakaszban rögzült spontán identitás áitalános érvénnyel van jelen a társadalomban és a térben. Az erre épülö, de már gondolati-ismereti elemeket is tartalmazó és nemzeti attitüdökben is megnyilvánuló „ideológiai” identitás feltételez egyfajta intellektuális tudatosságot, amely vélhetỏen a magasabb iskolázottsággal és véleményirányító státusszal jellemezhető társadalmi csoportok sajátja.

Az MTA Regionális Kutatások Központja Alföldi Tudományos Intézetében a nyolcvanas évek közepétől folynak, elsősorban a földrajzi identitás térelemeivel foglaikozó, kisebb területekre (falvak, városrészek, kistérségek) koncentráló kutatások 
(Csatári 1989; Nánásiné Tóth 1996; Hamar-Murányi-Szoboszlai 1997; MurányiSzoboszlai 1998; 1999). E vizsgálatok eredményeiből kitünik, hogy az identitást, mint általános társadalomtudományi és térfogalmat igen gyakran használjuk anélkül, hogy a fogalom bonyolult lokális, térségi, regionális kötődéseivel, tartalmával tisztában lennénk. Az elmúlt évtized(ek) relatív „tudatlansága” azért is fájó, mert például a fejlett nyugati országokban az identitásvizsgálatok régóta az egyik legdivatosabb interdiszciplináris kutatási iránynak tekinthetők (Krappman 1980), s Magyarországon is régóta esedékes a részletes, feltáró kutatások elvégzése.

Az eddigi kutatásokból (Csatári 1999; Nánásiné Tóth 1996; Murányi-Szoboszlai 1998) kiindulva kategorizálhatjuk, konkrét terekhez köthetjük a kötődés elemeket. Legerősebb a ragaszkodás a közvetlen lakókörnyezethez, a lokalitáshoz, s e viszony pozitív és/vagy negatív megítélése gyakran irreálisan vetül rá a tágabb földrajzi terek élettevékenységekkel kapcsolatos minősítésére is.

A táji-területi identitás három konkrét földrajzi téregységre határozható meg:

- a táji, történeti, termelési, kulturális, illetve bizonyos etnoregionális hagyományokban is gyökerező, az ott élő népesség tudatában mélyen leképeződö és valamilyen földrajzi tartalommal is bíró tájegységre, kistérségre vonatkozóan, valamint

- a megyére, mint történetileg is determinált, funkcionáló közigazgatási intézményrendszerrel rendelkező, a földrajzi identitás szempontjából területileg folyton változó képzödményre vonatkozóan, s végül

- a régióra vonatkozóan, mely az Uniós csatlakozás, a társadalomban és gazdaságban jelenleg is zajló európaizálódás eredményeként értékelődött föl.

A nemzeti és az európai identitás elemei - az említett vizsgálatok szerint - általában nem épülnek szervesen a részben értékelemeken nyugvó tradicionális lokális identitásra, illetve a konkrét geográfiai tartalommal bíró tereken alapuló (kistérségi, megyei, regionális) identitásra, hanem más, elsősorban tudati, politikai szimbólumrendszerben mutathatók ki. Ilyenek például a régi-új nemzeti jelképekhez való kötődés, a magyarságtudat megnyilvánulásainak eltérő megítélése, a Trianonszindróma újbóli felerősödése, de ide sorolható az európai szervezetekhez (NATO, Európai Unió) való csatlakozás kérdése is.

Empirikus vizsgálatokkal bizonyítható, hogy a társadalom földrajzi szempontból értékelhetó identitásának, illetve az identitás térelemeinek sajátos megnyilvánulásai fontos szerepet játszhatnak a jövő közigazgatási és területfejlesztési térfelosztásának meghatározásában. A kutatások stratégiai jelentősége abban van/lehet, hogy a polgárok földrajzi tájhoz, különböző létezö vagy megszervezett földrajzi terekhez (település, lakókörnyezet, kistérség, megye, régió stb.) való kötődésének minösége, annak belső harmóniája alapvetỏen - bár sokszor csak tudat alatt - befolyásolhatja életminőségüket, a területi jellegủ kihívásokra adott, a helyi társadalom által megfogalmazott válaszlehetőségeket, a mobilitást, a helyi, térségi közösség „,mi tudatának" erősségét. A szubjektumon átható vagy gyakran éppen az általa torzított, mégis objektiv területi törvényszerüségek ilyetén megközelítése kísérlet arra, hogy közelebb kerülhessünk azoknak a helyi-térségi társadalmi reakcióknak a megérté- 
séhez, amelyek napjaink igen dinamikus és sok esetben diffúz területi-társadalmi folyamatait kísérik. A társadalom tagjainak térbeli cselekvéseit, a különböző „politikákhoz" való viszonyulását nagymértékben megszabhatja, hogy milyenek például mentális térképeik, milyen térbeli konfliktusokat ismernek fel, milyen módon reagálnak azokra. S természetesen az is, hogy a szükségképpen kimerülö, kifejezetten térbeli jelleggel bíró konfliktusokat a helyi-térségi politikai vezetés és szakapparátus hogyan kezeli, mennyire számol azokkal a sajátos térbeli minősítésekkel, érzékelt terekkel, amelyekkel a polgárok rendelkeznek.

A kulturált és a közérdek által szabályozott térhasználat a magyar területi-települési fejlődés egyik igen fontos jövőbeli tényezője. Ez csak akkor lehet eredményes és sikeres, ha a szakmailag és tudományosan megalapozott fejlesztési elképzelések:

- Tudatosan számolnak azokkal a társadalmi-térhasználati tényezőkkel, amelyek részben az egyes állampolgárok mentális térképein jelennek meg;

- Megkeresik azokat a sajátos beavatkozási térformákat, amelyek az emberek térbeli mozgásaival, térhasználatával, térbeli cselekvési szokásaival részben vagy egészében egybeesnek;

- A különbözö térformákhoz világosan elkülönülő és adekvát feladatokat, intézményeket rendelnek;

- Közvetett és közvetlen módszerekkel (oktatás, továbbképzések, tudománynépszerüsítés stb.) mintegy „újratudatosítják” a modern és demokratikus társadalom térhasználatának fontosságát, annak kritériumrendszerét. Ez utóbbi kritériumrendszer elengedhetetlen feltétele annak, hogy a tulajdonviszonyok változását követően sokkal célszerübb és kulturáltabb térhasználat jöjjön létre, ugyanakkor azt egy civilizált, demokratikus, alulról építkező közélet és társadalomfejlődés térbeli szempontból is megalapozott szabályrendszere befolyásolja és ellenörizze.

Mindezek együttesen hozzájárulhatnak a területi-települési fejlődés sikereihez és remélt harmóniáihoz. Hipotézisünk szerint az emberek térbeli kötỏdései, a települési és térségi identitás-elemek vizsgálatából következő/levonható tanulságok igen nagymértékben segíthetik az egész területi fejlödési folyamatot, míg a kötődés „fogyatékosságai" - amelyek természetesen egyúttal a társadalom térbeli műveltségének hiányosságait is jelentik - gátolhatják, visszavethetik a területi-települési fejlödést, a társadalmi azonosulás mértékét, valódi támogatottságát. Különösen fontossá tehetik a ma még általunk is csak érintỏlegesen vizsgált identitás-tényezők szerepét az európai csatlakozás regionális politikai elvrendszerének olyan kitüntetett tényezői (kohézió, területi szolidaritás, a területi másság tisztelete stb.), amelyek alkalmazása egyik kitüntetett eleme a társadalom és a gazdaság térbelisége harmóniájának.

A következökben ismertetni kívánt regionális identitás-vizsgálat ${ }^{1}$ a Dél-Alföldi Régió operatív programjában „A helyi közösségek védőháló-szerepének újjászervezése, a civil szervezetek támogatása, a helyi, kistérségi és regionális kötődés erősítése" c. alprogram megalapozását, valamint a lokális és térségi identitáskutatás 
vizsgálati, módszertani bázisának, empirikus eredményeinek gyarapítását egyaránt jól szolgálhatja. Az 1999 októberében-novemberében végzett identitás-vizsgálat egy konkrét földrajzi térben (Dél-Alföld), szociológiai módszerekre épülő kutatás alapján mutat be egy szociálpszichológiai jelenség-együttest.

Hazai regionális empirikus előzmények hiányában a Dél-Alföldi Régió három megyéjében (Bács-Kiskun, Békés és Csongrád) készült kérdöives kutatásunk elsösorban a későbbi lokális és regionális identitás-vizsgálatok operacionalizálási problémáihoz nyújthat segítséget. A kutatás elsődleges célja annak feltárása volt, hogy a helyi, térségi kötödés területi alapkategóriáinak (lokalitás, régió, kistérség, megye) milyen reprezentációi vannak jelen az emberek gondolkodásában. A felderítő jellegü vizsgálat során ezért elsősorban a fogalomértelmezésekre koncentráltunk, ugyanakkor néhány aktuális, területfejlesztéssel kapcsolatos kérdés (régiók szerveződése, EU-csatlakozás) mellett kitértünk az értékrendek jellemzésére is.

\section{A régió és a kistérség fogalmának értelmezése}

A kérdezettek közel kétharmada (61\%) már hallott a Dél-Alföldi Régióról, s többségük (68\%) elött az is ismert, hogy melyik három megye tartozik a régióhoz. A kistérségekröl már kevesebben hallottak (41\%), és közülük egy vagy több konkrét kistérséget is kevesebben (48\%) tudtak megnevezni. A régióra illetve a kistérségekre vonatkozó ismeretkérdésekre adott válaszok megyénkénti szignifikáns eltérései annyiban következetesek, hogy minden esetben a Bács-Kiskun megyében élöket jellemzi a legnagyobb arányú ismerethiány. A három megyében élők a kérdőivben szereplö kritériumok mindegyikét inkább a régió fogalmának lényegéhez sorolták (60 pont feletti átlagok), azonban két szempontot (a területek földrajzi összetartozása illetve jó megközelíthetösége) különösen fontosnak tartanak (1. táblázat). Mindez arra utal, hogy a lakosság számára a régió inkább fơldrajzi, mint társadalmitơrténeti fogalom.

\section{TÁBLÁZAT}

Ön szerint a felsoroltak mennyiben tartoznak a régió lényegéhez?*

(In Your Opinion, How Closely Do the Listed Elements Belong to the Essence of the Region?)

\begin{tabular}{lcccc}
\hline & Régió & $\begin{array}{c}\text { Bács- } \\
\text { Kiskun }\end{array}$ & Békés & Csongrád \\
\hline A területek földrajzi összetartozása & 79 & 81 & 76 & 80 \\
A területek jó megközelíthetősége & 70 & 72 & 70 & 69 \\
Az ott élök közös érdeke & 67 & 69 & 62 & 70 \\
$\begin{array}{l}\text { A területen található cégek közös gazdasági } \\
\text { kapcsolatai }\end{array}$ & 65 & 66 & 63 & 66 \\
Az ott élök hasonló információs-kommuni- & 64 & 63 & 65 & 76 \\
kációs szokásai, csatornái & & & & \\
Az ott élök közös hagyományai, tradíciói & 62 & 60 & 56 & 63 \\
Az ott élök társadalmi, szociális hasonlósága & 60 & 60 & 56 & 63 \\
\hline
\end{tabular}

*Százfokozatú skálára transzformált értékek: 0: egyáltalán nem, 100: teljes mértékben.

Forrás: Identitás-vizsgálat a Dél-Alföldi Régióban 1999. 
Az ugyanezen kritériumokkal mért kistérség-fogalom értelmezésében szintén kiemelt szerepe van a földrajzi szempontoknak, azonban - szemben a régióértelmezéssel - a kistérségben élők közös érdeke és tradíciói ugyanolyan súlyúak, mivel a kisebb területi integráció inkább rendelkezik az emberi közösség jellegzetességeire (hagyomány, érdek) utaló vonásokkal (2. táblázat). A megyék közötti szignifikáns eltérések azt mutatják, hogy mindkét fogalom esetében azon kritériumok megitélése eltérỏ, amelyek a társas együttélés sajátosságait (szociális-társadalmi hasonlóság, hagyomány, érdek) tartalmazzák. A százfokozatú skálára transzformált átlagok szerint leginkább a Csongrád megyében élők, legkevésbé pedig a Békés megyeiek tartják fontosnak a közösségi-társadalmi szempontokat a régió illetve a kistérség fogalmának értelmezésénél.

\section{TÁBLÁZAT}

Ön szerint a felsoroltak mennyiben tartoznak a kistérség lényegéhez?*

(In Your Opinion, How Closely Do the Listed Elements Belong to the Essence of the Micro-Region?)

\begin{tabular}{lcccc}
\hline & Régió & $\begin{array}{c}\text { Bács- } \\
\text { Kiskun }\end{array}$ & Békés & Csongrád \\
\hline A területek földrajzi összetartozása & 76 & 75 & 77 & 75 \\
Az ott élök közös érdeke & 75 & 80 & 70 & 77 \\
Az ott élök közös hagyományai, & 73 & 76 & 67 & 75 \\
tradíciói & 71 & 73 & 72 & 68 \\
$\begin{array}{l}\text { A területek jó megközelíthetôsége } \\
\text { Az ott élők hasonló információs- } \\
\text { kommunikációs szokásai, csatornái }\end{array}$ & 69 & 69 & 71 & 67 \\
$\begin{array}{l}\text { Az ott élók társadalmi, szociális ha- } \\
\text { sonlósága }\end{array}$ & 67 & 66 & 64 & 71 \\
$\begin{array}{l}\text { A területen található cégek közös } \\
\text { gazdasági kapcsolatai }\end{array}$ & 66 & 67 & 67 & 65 \\
\hline
\end{tabular}

*Százfokozatú skálára transzformált értékek: 0: egyáltalán nem, 100: teljes mértékben.

Forrás: Identitás-vizsgálat a Dél-Alföldi Régióban 1999.

A főkomponens-analizis azonos logika alapján rendezte két típusba a régió illetve a kistérség értelmezését. Mindkét esetben jelentősen nagyobb magyarázott varianciával bír a „társadalmi” értelmezés-típus, amelyben a közös hagyományoknak van a legnagyobb, míg a gazdasági kapcsolatoknak a legkisebb súlya.

A százfokozatú skála átlagainak megfelelően a régió illetve a kistérség fogalmi típusai közuil mindkét esetben csak a "társadalmi” értelmezési típus átlagosnál nagyobb elfogadásában, illetve elutasításában van különbség a megyék között: a Csongrád megyeiekre az előbbi, míg a Békés megyében élőkre az utóbbi a jellemző. A megyei almintákon belül, külön-külön vizsgált regressziós modellek egyik tanulsága, hogy a régió és a kistérség értelmezései közül a „földrajzi” típust mindegyik megyében jobban magyarázzák a független változók, mint a "társadalmi”" fogalmi értelmezést. A másik tanulság, hogy a magyarázó változók minden esetben a Bács-Kiskun megyeiek régió- és kistérség értelmezésére vannak a legnagyobb, a 
csongrádiakéra pedig a legkisebb hatással. A szignifikáns független változók közül a lakỏhely szerepe egyértelmü: a „földrajzi” régió- és kistérség-értelmezéssel történő azonosulást mindhárom megyében jobban valószinüsíti, ha valaki községben él.

\section{A lokális és a térségi kötődés elemei}

A tágabb vagy szükebb lakóhelyhez kötődés szubjektív és objektív elemei közül 15 lehetséges kapcsolódási indokot vizsgáltunk. A régióhoz való ragaszkodás leginkább meghatározó elemei (50 pont feletti átlagértékekkel) a környezet esztétikája és a lokálpatriótizmus mellett a rokoni és baráti kapcsolatok, legkevésbé a szabadidő eltöltésének kedvező lehetőségei és az anyagi jellegű feltételek (az elköltözés pénzügyi fedezete, telek- és ingatlan árak) hiánya voltak. A megyéhez és a kistérséghez való kötődést ugyanezek jellemzik, de az indoklások egyetértési átlagai magasabbak. Úgy véljük, hogy a megye és a kistérség közel azonos megítélése azt jelzi, hogy a lakosság nem különíti el a két kategóriát. A konkrét lakóhelyhez, azaz a településhez való viszony egyértelmúen mást jelent az emberek számára. Megnőtt az 50 pont feletti indoklások száma, illetve olyan indoklások váltak fontossá, amelyek a mindennapi élettel kapcsolatosak (házasság, munkahely, megélhetés, közlekedés).

A legtöbb esetben szignifikáns megyénkénti eltérések érdekes trendeket jeleznek. A régió, a megye és a kistérség esetében a legtöbb indoklásnál a Bács-Kiskun megyében élők átlaga a legalacsonyabb, míg a Csongrád megyeiek átlaga a legmagasabb. A településhez való kötődés intenzitása viszont a Békés megyeiek körében a legalacsonyabb, elsősorban az egzisztenciális és infrastrukturális feltételekre vonatkozó indoklások esetében (környezet, szellemi kötődés, a település fejlettsége, közlekedési viszonyok, munkalehetőség, megélhetés, a gyerekek jövője, szabadidős lehetőségek, ingatlanárak).

A külön-külön elvégzett fökomponens-analízis mind a négy esetben (régió, megye, kistérség, település) azonos logikájú „kötödés-típusokat” eredményezett (3. táblázat). Ez azt jelenti, hogy a három megye lakossága azonos tartalmi megközelítéssel viszonyul a lakókörnyezet különböző szintjeihez. A legnagyobb magyarázott varianciával rendelkezö infrastrukturális típusokban olyan indoklások együttes preferálása szerepel, amelyek a lakóhelyi környezet minőségi jellemzőire vonatkoznak (közlekedés, fejlettség, esztétikum, a szabadidő eltöltésének lehetöségei). Az ,infrastrukturális” típusnál jelentősen alacsonyabb, de közel azonos varianciájú másik két fökomponensbe tartozó indoklások logikája mindegyik szint esetében egyértelmü: a munkahely és megélhetés mellett (,munkahely”) a családi-rokoni és ismerősi szfẻrára vonatkozó kötődések („család-kapcsolat”) alkotnak külön típusokat. A régió, a megye és a kistẻrség esetében a negyedik fökomponensben az elköltözéshez szükséges anyagiak hiányát hangsúlyozó és a lokálpatriotizmust (a lakóhely szeretetét) elutasító (negatív faktorsúly) „anti-kötődések” fogalmazódnak meg. A települẻsi szint negyedik főkomponense ugyanezeket az elemeket tartalmazza, de 
ellenkező elöjellel: a lakóhely iránti szeretet és a tágabb-szükebb emberi kapcsolatok pozitív, míg az elköltözés szándékát feltételező kijelentés negatív súllyal van jelen (,nem elköltöző” típus).

A különböző lakóhelyi környezethez való kötődés azonos logikájú „kötődéstípusai" együttes szerveződésének figyelembevétele során a 16 fökomponens bevonásával másodlagos fökomponens-analízist végeztünk. Az eredmények egyértelmüen igazolják, hogy az eltérỏ lakókörnyezeti szintekhez való kötődés azonos logikájú szerveződései nem függetlenek egymástól.

A másodlagos fókomponensek megyei score-átlagai jelentős eltéréseket mutatnak: a Csongrád megyeiket az „infrastruktúra” és a „munkahely” típus az átlagosnál jobban, míg a Békés megyében élőket az átlagosnál kisebb mértékben jellemzi. A tárgyi-gazdasági feltételrendszer átlagosnál kisebb mértékü preferálása mellett más eredmények is alátámasztják, hogy a Békés megyeiek inkább érzelmileg ragaszkodnak tágan értelmezett (település-régió) lakókörnyezetükhöz: a családi-rokoni kötődések (,család-kapcsolat”) csak az itt élőket jellemzik a régió átlagánál nagyobb mértékben. Mindez együtt jár az elköltözési szándékot és a lakóhely szeretetét tartalmazó „elköltöző” típus elutasításával. A Csongrád megyében élők kötődése bizonyos értelemben "hideg”, mivel a megélhetési és infrastrukturális szempontokat preferálják legerősebben, ám hozzájuk képest a Bács-Kiskun megyeiek viszonyulása még inkább elgondolkodtató, mert csak az itt élőket jellemzi az „elköltözés" típus átlagosnál erösebb preferálása.

\section{TÁBLÁZAT}

Az egyes területi szintekhez való kötödés alapján elkülönitett típusok (Types Designated by the Belonging to the Individual Territorial Levels) A régióhoz való kötődés alapján elkülönitett típusok

\begin{tabular}{|c|c|c|c|}
\hline $\begin{array}{c}\text { „Infrastruktúra" } \\
(43,0) \\
\end{array}$ & $\begin{array}{c}\text { "Család-kapcsolat" } \\
(8,2)\end{array}$ & $\begin{array}{c}\text {,Munkahely" } \\
(7,8)\end{array}$ & $\begin{array}{c}\text { „Elköltözö" } \\
(7,2)\end{array}$ \\
\hline $\begin{array}{l}\text { A település } \\
\text { fejlettsége }\end{array}$ & Emberi kapcsolatok & $\begin{array}{c}\text { Munkalehetőség, } \\
\text { munkahely }\end{array}$ & $\begin{array}{c}\text { Az elköltơzés- } \\
\text { hez szuikséges } \\
\text { pénz hiánya }\end{array}$ \\
\hline Szép környezet & Házasság & Megélhetés & $\begin{array}{l}\text { A lakóhely } \\
\text { szeretete (-) }\end{array}$ \\
\hline Jó közlekedés & Egészségi állapot & Szellemi kötődés & $\begin{array}{c}\text { Szép környezet } \\
(-)\end{array}$ \\
\hline $\begin{array}{l}\text { Szabadidös } \\
\text { lehetöségek }\end{array}$ & A gyerekek jövője & $\begin{array}{l}\text { A lakóhely } \\
\text { szeretete }\end{array}$ & \\
\hline
\end{tabular}


A megyéhez való kötỏdés alapján elkülönitett típusok

\begin{tabular}{|c|c|c|c|}
\hline $\begin{array}{c}\text { "Infrastruktúra" } \\
(38,9)\end{array}$ & $\begin{array}{c}\text { „Munkahely" } \\
(8,9)\end{array}$ & $\begin{array}{c}\text { "Család- } \\
\text { kapcsolat" }(8,2)\end{array}$ & $\begin{array}{c}\text { "Elköltözö" } \\
(7,5)\end{array}$ \\
\hline $\begin{array}{l}\text { A település } \\
\text { fejlettsége }\end{array}$ & $\begin{array}{l}\text { Munkalehetőség, } \\
\text { munkahely }\end{array}$ & $\begin{array}{c}\text { Rokoni } \\
\text { kapcsolatok }\end{array}$ & $\begin{array}{l}\text { Az elköltözźshez } \\
\text { szükséges pénz } \\
\text { hiánya }\end{array}$ \\
\hline Szép környezet & Megélhetés & Házasság & $\begin{array}{c}\text { Szép környezet } \\
(-)\end{array}$ \\
\hline Jó közlekedés & Szellemi kötődés & $\begin{array}{l}\text { A gyerekek } \\
\text { jövője }\end{array}$ & $\begin{array}{l}\text { A lakóhely } \\
\text { szeretete (-) }\end{array}$ \\
\hline $\begin{array}{l}\text { Szabadidős } \\
\text { lehetőségek }\end{array}$ & $\begin{array}{l}\text { A lakóhely } \\
\text { szeretete }\end{array}$ & $\begin{array}{c}\text { Emberi kapcso- } \\
\text { latok }\end{array}$ & \\
\hline $\begin{array}{l}\text { Egészségi } \\
\text { állapot }\end{array}$ & & Egészségi állapot & \\
\hline $\begin{array}{l}\text { Telek- és } \\
\text { ingatlanárak }\end{array}$ & & $\begin{array}{c}\text { Szabadidős } \\
\text { lehetőségek (-) }\end{array}$ & \\
\hline
\end{tabular}

A kistérséghez való kötödés alapján elkülönitett típusok

\begin{tabular}{|c|c|c|c|}
\hline $\begin{array}{c}. \text {.Infrastruktúra" } \\
(36,7)\end{array}$ & $\begin{array}{c}\text { "Család-kapcsolat" } \\
(8,7)\end{array}$ & $\begin{array}{c}\text { "Munkahely" } \\
(8,3)\end{array}$ & $\begin{array}{c}\text { „Elköltözö" } \\
(7,9)\end{array}$ \\
\hline Szép környezet & Rokoni kapcsolatok & Munkalehetöség & $\begin{array}{l}\text { Az elköltözéshez } \\
\text { szükséges pénz } \\
\text { hiánya }\end{array}$ \\
\hline $\begin{array}{l}\text { A település } \\
\text { fejlettsége }\end{array}$ & Házasság & Megélhetés & $\begin{array}{l}\text { Telek - és } \\
\text { ingatlanárak }\end{array}$ \\
\hline $\begin{array}{c}\text { Kedvezö } \\
\text { szabadidös } \\
\text { lehetöségek }\end{array}$ & Egészségi állapot & Szellemi kötődés & \\
\hline Jó közlekedés & Emberi kapcsolatok & & \\
\hline $\begin{array}{l}\text { A lakóhely } \\
\text { szeretete }\end{array}$ & A gyerekek jövője & & \\
\hline
\end{tabular}

A településhez való kötödés alapján elkülönitett típusok

\begin{tabular}{|c|c|c|c|}
\hline $\begin{array}{c}\text { "Infrastruktúra" } \\
(28,5)\end{array}$ & $\begin{array}{c}\text { "Család-kapcsolat" } \\
(10,0)\end{array}$ & $\begin{array}{c}\text { „Munkahely" } \\
(9,4)\end{array}$ & $\begin{array}{c}\text { „Nem elköltözö" } \\
(8,7)\end{array}$ \\
\hline $\begin{array}{l}\text { A telepúlés } \\
\text { fejlettsége }\end{array}$ & Házasság & Munkalehetőség & $\begin{array}{l}\text { A lakóhely sze- } \\
\text { retete }\end{array}$ \\
\hline $\begin{array}{c}\text { Kedvező } \\
\text { szabadidős } \\
\text { lehetőségek }\end{array}$ & A gyerekek jövője & Megélhetés & $\begin{array}{l}\text { Az elköltözéshez } \\
\text { szükséges pénz } \\
\text { hiánya (-) }\end{array}$ \\
\hline Szép környezet & Rokoni kapcsolatok & Szellemi kötödés & $\begin{array}{c}\text { Emberi } \\
\text { kapcsolatok }\end{array}$ \\
\hline Jó közlekedés & Egészségi állapot & & $\begin{array}{c}\text { Rokoni } \\
\text { kapcsolatok }\end{array}$ \\
\hline
\end{tabular}

Forrás: Identitás-vizsgálat a Dél-Alföldi Régióban 1999. 
A regressziós modellek azt támasztják alá, hogy a három megye közül a Békés megyeiek esetében mindegyik „kötődés-típust” nagymértékben befolyásolják a bevont független változók, míg Bács-Kiskun megyében - a személyes kapcsolati típus kivételével - a magyarázó változók hatása a legkevésbé erős. A függőnek tekintett másodlagos fökomponensek közül a „család-kapcsolat” esetében mindhárom megyében magas a magyarázott variancia-hányad, s nem meglepö, hogy különösen a házas családi állapot és a lakóhelyhez való „hüség” a régió mindegyik megyéjében meghatározza a családi-rokoni kötödések hangsúlyozását. Az elköltözési szándékot („elköltöző” típus) minden almintában (megyében) szignifikánsan növeli, ha a válaszadó házas, $s$ két megyében (Bács-Kiskun és Csongrád) az életkornak is szerepe van: a fiatalság valószínüsíti az elköltözési szándékot. A település, mint lakóhely (szignifikáns) befolyásoló hatása ellentmondásos: a születésüktől fogva a településen élök Csongrád megyében inkább elköltöznének, míg Békés megyében ellentétes trend érvényesül. A közlekedés, a fejlettség, más szóval az „infrastrukturális" tényezők, mint kötődési szempontok megítélését csak Békés megyében befolyásolják nagymértékben a szocio-kulturális jellemzök. A három megye közös sajátossága, hogy az „egyházhü” változó mindegyik modellben szignifikáns volt. A látszólag meglepö állitás - a lakókörnyezet infrastrukturális jellemzői annál inkább kötődési szempontok, minél inkább vallásos valaki - magyarázata vélhetően a vallásosság más szocio-kulturális jellemzőkkel való kapcsolatával magyarázható. Mivel az intenzíven vallásos emberek körében felülreprezentáltak az inaktívak és a kevésbé iskolázottak, logikusnak tủnik, hogy a Bács-Kiskun és a Békés megyei modellekben az "infrastruktúra" kötődési típusra az aktív foglalkozási státusz és a felsőfokú végzettség hatása negatív. Mindez arra utal, hogy nem a vallásosság szerint elkülönült csoportok tényleges vallásosságának, hanem a mögöttes jellemzöknek van befolyásoló hatása.

A foglalkoztatottság, mint kötődési szempont („munkahely” fökomponens) magyarázatában mindhárom megyei modellben szignifikáns a foglalkozási aktivitás hatása: az aktív dolgozói státusz inkább valószínüsíti ennek a kötődési típusnak a preferálását. A lakókörnyezethez való kötődésben egyértelmúen Békés megyében jelenti a leginkább meghatározó tényezőt a munka világa. Ezt nemcsak a magas magyarázott variancia-hányad $(43,6 \%)$, hanem az is jelzi, hogy hét szociokulturális változónak is szignifikáns hatása van. (A következő jellemzőkkel leírható személyek körében valószínüsíthető a foglalkoztatottság-megélhetés, mint kötődési szempont preferálása: aktívak, házasok, fiatalok, nök, községi lakosok, születésük óta a lakóhelyükön élők, nem vallásosak.)

Mint láttuk, a régióhoz, megyéhez és a kistérséghez való kötỏdés - egyre növekvő mértékben - közel azonos struktúrájú, míg a lakóhelyi kapcsolódásban „megjelenik" a konkrét életfeltételek preferálása. Az emberek életében a település szerepe a globális értékelésben is érvényesül, mivel az „Összességében hogy érzi magát?" kérdésre a lakóhely kapta a legmagasabb pozitív értékelést (81 pont), de a másik három tágabb környezetre vonatkozó átlag is igen magas (76-78 pont). A megyei 
alminták szignifikáns eltérései egyértelmü sorrendet mutatnak mindegyik esetben, mivel - a dél-alföldi régió egészéhez viszonyítva - a régió, a megye, a kistérség és a lakóhely több szempontú minősítése Csongrád megyében a legjobb, $s$ Békés megyében a legrosszabb.

A területi-lakóhelyi kötödésre vonatkozó másik kérdésünkre - „Milyen jelentöségủek az Ön életében az alábbiak?" - adott válaszok transzformált átlagai azt igazolják, hogy a régióban élök a fokozatosan táguló lakókörnyezet minden elemét fontosnak tartják (74-85 pont) (4. táblázat). A lokálpatriotizmus és a „természetes" nacionalizmus következménye, hogy a konkrét lakóhely illetve az ország jelentőségének megitélése kiemelkedik a közel azonos átlaggal jellemezhető egyéb környezeti szintek közül. A megyék közötti különbségek közül megemlíthetjük, hogy a Bács-Kiskun megyeiek számára a kistérség és Európa kevésbé, míg a Csongrád megyeiek számára az „utca” inkább fontos, mint a másik két megyében.

\section{TÁBLÁZAT}

Milyen jelentöségũek az Ön életében az alábbiak? Értékeljen fontosság szerint!*

(How Important Are the Below-Listed in Your Life? Evaluate Them by Order of Importance!)

\begin{tabular}{lcccc}
\hline & Régió & $\begin{array}{c}\text { Bács- } \\
\text { Kiskun }\end{array}$ & Békés & Csongrád \\
\hline Az ország, amelynek állampolgára & 85 & 83 & 88 & 85 \\
A város vagy falu, ahol él & 83 & 81 & 82 & 85 \\
A tágabb kontinens (Európa), ahol & 78 & 76 & 81 & 80 \\
élünk & 78 & 76 & 77 & 80 \\
Az utca, ahol lakik & 74 & 73 & 73 & 77 \\
A település, ahol dolgozik vagy & 74 & 69 & 77 & 78 \\
tanul & A kistérség, ahol lakik &
\end{tabular}

*Százfokozatú skálára transzformált értékek: 0: egyáltalán nem, 100: teljes mértékben.

Forrás: Identitás-vizsgálat a Dél-Alföldi Régióban 1999.

A területi hovatartozás különbözö szintjeit szubjektiv jelentőség alapján besoroló hat változó két, jól elkülönülö típusba szervezödött. Lényegesen nagyobb magyarázott variancia-hányad jellemzi az első fökomponenst („közvetlen környezet”), amelyben a közvetlen lakóhely és a kistérség jelentöségének együttes preferálása, míg a másik típusban az állampolgárság és az európaiság területi fontossága van jelen. A megyéket csak ez utóbbi típus osztja meg, mivel a Békés megyében élökre a nemzeti és európai keretek jelentőségének az átlagosnál nagyobb, a Bács-Kiskun megyeiekre az átlagosnál kisebb megítélése jellemző.

A regressziós modellek közül csak Békés megyében és csak az egyik esetben („közvetlen környezet”) magyarázóak jelentősebb mértékben a szocio-kulturális jellemzők. A magyarázó tényezök közül mindegyik megyében szignifikáns az iskolai végzettség hatása, pontosabban, az alacsony iskolázottság (legfeljebb szakmunkásképző) a régióban egységesen befolyásolja a szükebb lakóhely jelentőségé- 
nek felértékelését. A közvetlen környezet pozitív értékelésében Bács-Kiskun és Békés megyében is szignifikáns a településhez való kötődés, vagyis az a tény, hogy valaki születésétől fogva ugyanazon a településen él nagymértékben valószínűsíti, hogy számára nem közömbös szükebb lakóhelyi környezete. Annak ellenére, hogy konkrét magyarázatot csak hipotetikus szinten tudnánk megfogalmazni, mégis megemlítjük, hogy a másik független változó esetében (,tágabb környezet”) szintén Bács-Kiskun és Békés megyében szignifikáns befolyásoló tényező a felekezeti hovatartozás: a református vallás inkább kizárja a tágabb területi hovatartozás fontosságának elismerését.

\section{A lokálpatriotizmus jellemzői}

Már az eddigiekben is többször utaltunk a lakóhelyhez való ragaszkodás terminusra, pontosabban a lokálpatriotizmusra. A hétköznapi és a „hivatalos" megközelítés ${ }^{2}$ egyaránt magában foglalja az érzelmi jellegü viszonyulást (,szeretet”), ezért már a kérdésben jelöltük a fogalom ismert jellemzőjét és négy másik értelmezési dimenziót is szerepeltettünk.

A lokálpatriotizmus feltételezett tartalmi kritériumai közül három esetben (kulturális, gazdasági, szociális) inkább a megosztottság jellemzi a régió lakosságának fogalomértelmezését, míg a negyedik esetben már egyértelmü többség zárja ki a politikai tevékenységet illetve magatartást a terminus meghatározásából (5. táblázat). Az emberek többsége számára a politikamentes lokálpatriotizmus inkább kulturális, gazdasági és szociális tartalmú, de az 53-59\%-os ,igen” válaszok aránya nem tükröz kizárólagos egyetértést. A három megyei alminta válaszainak - szignifikáns - eltérése arra utal, hogy leginkább a Csongrád megyeiek, a legkevésbé pedig a Bács-Kiskun megyében élők vélik azt, hogy a felsorolt négy „társadalmi alrendszer" cselekvésében és magatartásában része lenne a lokálpatriotizmusnak.

\section{TÁBLÁZAT}

Ön szerint hogyan jelentkezik a lokálpatriotizmus, a lakóhely fokozottabb szeretete?*

(How Do You Think Local Patriotism, a More Intensive Affection Towards the Place of Residence is Demonstrated?)

\begin{tabular}{lcccc}
\hline & Régió & $\begin{array}{c}\text { Bács- } \\
\text { Kiskun }\end{array}$ & Békés & Csongrád \\
\hline $\begin{array}{l}\text { Kulturális tevékenységben, } \\
\text { magatartásban }\end{array}$ & 59 & 54 & 63 & 61 \\
$\begin{array}{l}\text { Gazdasági tevékenységben, } \\
\text { magatartásban }\end{array}$ & 54 & 48 & 55 & 60 \\
$\begin{array}{l}\text { Szociális tevékenységben, } \\
\text { magatartásban }\end{array}$ & 53 & 50 & 50 & 60 \\
$\begin{array}{l}\text { Politikai tevékenységben, } \\
\text { magatartásban }\end{array}$ & 39 & 32 & 39 & 48 \\
\hline
\end{tabular}

* Az „igen" válaszok százalékos megoszlása.

Forrás: Identitás-vizsgálat a Dél-Alföldi Régióban 1999. 
A négy tartalmi kritérium bevonásával elvégzett klaszteranalízis két olyan csoportra osztja a régió lakosságát, melyek alapvetően eltérnek a lokálpatriotizmus megítélésében. A nagyobb elemszámú csoportban (a minta 59 százaléka: „gyenge lokálpatrióták") még a fogalom magyarázatába leginkább beemelt kulturális szempont egyetértési aránya is csak $33 \%$, míg a másik csoport $83 \%$-a a politikai tevékenységet illetve magatartást is a lokálpatriotizmus fogalmához sorolja („erös” lokálpatrióták) (6. táblázat).

\section{TÁBLÁZAT}

A lokálpatriotizmus fogalmának értelmezése alapján elkülönült két klaszter jellemzói* (Characteristics of the Two Clusters Designated by the Comprehension of the Concept of Local Patriotism)

\begin{tabular}{lcc}
\hline & "Gyenge" lokálpatrióták & „Erös" lokálpatrióták \\
\hline $\begin{array}{l}\text { Kulturális tevékenységben, } \\
\text { magatartásban }\end{array}$ & 33 & $91 \%$ \\
$\begin{array}{l}\text { Politikai tevékenységben, } \\
\text { magatartásban }\end{array}$ & 9 & 83 \\
$\begin{array}{l}\text { Gazdasági tevékenységben, } \\
\text { magatartásban }\end{array}$ & 25 & 93 \\
$\begin{array}{l}\text { Szociális tevékenységben, } \\
\text { magatartásban }\end{array}$ & 23 & 96 \\
\hline
\end{tabular}

*Az ,igen" válaszok százalékos megoszlása, illetve a klaszterek aránya a mintában.

Forrás: Identitás-vizsgálat a Dél-Alföldi Régióban 1999.

A kijelentések százalékos megoszlásához hasonlóan, a lokálpatriotizmus szük értelmezése leginkább (62\%) a Bács-Kiskun megyeiekre, legkevésbé (54\%) a Csongrád megyében élőkre jellemzö. ${ }^{3} \mathrm{~A}$ regressziós modellek alapján kijelenthetjük, hogy a szocio-kulturális jellemzők a három megye közül egyikben sem - legkevésbé Csongrád megyében - játszanak meghatározó szerepet abban, hogy valaki a „tág” vagy a „szúk” lokálpatrióta csoportba tartozik (a magyarázott varianciahányad csupán 2,0-5,5\%). A lakóhelyi lokálpatriotizmust a régióban élók inkább erősnek, mint gyengének vélik (65 pont), azonban Bács-Kiskun és Csongrád megyéhez képest Békésben ez az átlag alacsonyabb (59 pont).

Nem meglepő, hogy megfelelö anyagi feltételek esetén a lakóhely elhagyására vállalkozók aránya szintén Békés megyében a legmagasabb (26\%), de nem alacsony a régió egészét tekintve sem, mivel, ha elegendö pénze lenne, minden ötödik válaszadó (21\%) elköltözne jelenlegi településéröl.

A lakóhelyet változtatók/lakóhelyváltoztatásra vállalkozók relatív többsége (34\%) valamelyik dunántúli településre költözne, emellett még a dél-alföldi városok megnevezése volt számottevő (20\%). A költözési célok nagymértékben eltérnek a három megyében: a Bács-Kiskun megyeiek a Dunántúl (22\%) mellett elsősorban valamelyik dél-alföldi megyeszékhelyet $(21 \%)$ vagy várost (16\%) választanák, míg a Békés megyei mobilitás elsősorban a Dunántúlra (49\%) irányulna. A régió másik két megyéjéhez viszonyítva Csongrád megyéböl nagyobb arányban költöznének a fövárosba (17\%), s kevesebben mennének valamelyik dél-alföldi megyeszékhelyre (7\%) (7. táblázat). 


\section{TÁBLÁZAT \\ Ha elköltözne, hova menne?*}

(If You Moved Out, Where Would You Go?)

\begin{tabular}{lcccc}
\hline & Régió & $\begin{array}{c}\text { Bács- } \\
\text { Kiskun }\end{array}$ & Békés & Csongrád \\
\hline A Dunántúl településeire & 34 & 22 & 49 & 29 \\
Valamelyik dél-alföldi városba & 20 & 16 & 22 & 25 \\
Valamelyik dél-alföldi megyeszékhelyre & 14 & 21 & 14 & 7 \\
A fövárosba & 10 & 7 & 6 & 17 \\
Küllföldre & 10 & 13 & 3 & 11 \\
Az Alföld más településére & 5 & 5 & 6 & 4 \\
Valamelyik dél-alföldi faluba & 4 & 7 & 0 & 6 \\
Nem tudja & 4 & 10 & 1 & 1 \\
\hline
\end{tabular}

*Oszlopszázalékban.

Forrás: Identitás-vizsgálat a Dél-Alföldi Régióban 1999.

A lokálpatriotizmus jelenlétét legkevésbé érzékelő és a lakóhelyükröl leginkább elköltözni vágyó Békés megyeiek statisztikailag is jelentösen - szignifikánsan gyakrabban foglalkoznak szükebb (település) és tágabb (kistérség, megye, régió) lakókömyezetükkel, mint a másik két megyében élők. A Bács-Kiskun megyeieket a régió egészéhez viszonyítva - következetesen alacsony átlagok jellemzik, azonban mind a megyékre, mind a régióra igaz, hogy az emberek inkább ritkábban, mint gyakran gondolnak lakókörnyezetükre (50 pont alatti átlagok).

\section{Értékek a lakókörnyezetben}

A helyi társadalom értékrendje összetett és soktényezös probléma, melynek részletes vizsgálatára nem vállalkozhattunk. A későbbi kutatások megalapozását azonban elösegithetik azok az eredmények, amelyek egy sajátos megközelítésben a lakóhelyen élök különböző szempontok szerinti értékelésére vonatkoznak. Úgy véljük, hogy az egyes emberek lakossági elfogadását minösítö szubjektív ítéletek jól tükrözik a régió, illetve a megyék lakóhelyi értékrendjének bizonyos sajátosságait.

A két lakókörnyezeti szintre vonatkozó kérdéseink közül a konkrét település esetében olyan kritériumokat fogalmaztunk meg, amelyek egyrészt a lakóhelyhez való kötődésre (származás, beköltözés), illetve az effektív törődésre (sokat tesz a településért), másrészt státusz-jellemzőkre (iskolázottság, vezetés, politikai funkció, egzisztenciális helyzet, vallásosság) vonatkoztak. Az átláthatóság problémája miatt a régióra vonatkozó kérdésben nem a szempont csoport, hanem a területi hovatartozás különböző kritériumainak megitélése szerepelt.

Az eredmények szerint a régióban élök többsége (59 pont feletti átlagok) véli úgy, hogy a településen élök elismerésében leginkább a lakóhelyi kötödés, a helyi vezetői pozíció, az iskolázottság valamint a biztos anyagi háttér számít (8. táblázat). Ezekkel szemben a beköltözés vagy visszatelepülés, a vallásosság és a pártelkötelezettség kevésbé fontos tényezők (31-49 pont). A régió átlagához viszonyitva, a helyi elismertség szempontjából Békés megyében a közigazgatási és pártvezetői státuszt fontosnak, míg Csongrád megyében kevésbé fontosnak tartják az ott élök. 


\section{TÁBLÁZAT}

Lakóhelyén az egyes emberek elismerésében mennyire számit az, hogy, ha valaki(nek)...*

(The Recognition of an Individual in His/Her Place of Residence Depends on How the Individual...)

\begin{tabular}{lcccc}
\hline & Régió & $\begin{array}{c}\text { Bács- } \\
\text { Kiskun }\end{array}$ & Békés & Csongrád \\
\hline Sokat tesz a faluért/városért & 70 & 73 & 68 & 68 \\
Sok pénze van & 69 & 68 & 71 & 66 \\
A falu/város vezetői közé tartozik & 66 & 65 & 75 & 58 \\
Iskolázott & 65 & 67 & 61 & 65 \\
Családja régóta él a településen & 59 & 61 & 56 & 59 \\
Valamilyen pártfunkciója van & 49 & 49 & 56 & 41 \\
Vallásos & 32 & 38 & 24 & 33 \\
A városból vissza/kitelepült vagy a & 31 & 32 & 24 & 34 \\
faluból betelepült/ beköltözött & & & & \\
\hline
\end{tabular}

*Százfokozatú skálára transzformált értékek: 0: egyáltalán nem, 100: sokat számít.

Forrás: Identitás-vizsgálat a Dél-Alföldi Régióban 1999.

A lakóhelyi elismertség fökomponens-analízis segítségével kialakított három típusa közül a vezetỏi és pártfunkciókat az egzisztenciális biztonsággal összekapcsoló „elit” esetében legmagasabb a magyarázott variancia. A második típus (,lokálpatrióta") a lakóhelyhez való kötődést és a vallásosságot képviseli, míg a harmadik az iskolázottságot a lakóhely problémáival való törődéssel köti össze (,értelmiségi").

A megyei almintákat jellemző score-átlagok azt igazolják, hogy a lakóhelyi elismertséget tekintve a Békés megyeiek a vezetői státuszt (,elit”) az átlagosnál jobban, míg a lakóhelyhez való kötődést („lokálpatriotizmus”) kevésbé vélik lényegesnek. A másik két megyei almintában viszont pozitiv a lakóhelyhez való kötődés típusának score-átlaga, ami arra utal, hogy az itt élök a régió átlagánál fontosabbnak tartják a lokálpatriotizmust a helyi lakosság értékrendjében. (A Csongrád megyeieket ezen kívül még az is jellemzi, hogy a vezetői pozíciót kevésbé tekintik presztízs-szempontnak).

A szocio-kulturális jellemzök csak Békés megyében befolyásolják számottevően az „elit” típusú elismertséget. A „lokálpatrióta” típus elfogadását, illetve elutasítását azonban itt módosítják legkevésbé a független változók. Mivel a „lokálpatrióta” típusban a lakóhely iránti ragaszkodás a vallásossággal kapcsolódik össze, logikus, hogy a nem ateista csoportba való tartozás mindegyik megyében valószínüsíti a típus preferálását. További sajátosság, hogy a független változók mindhárom megyében igen csekély mértékben befolyásolják az „értelmiségi” vélemény-típust.

A regionális elismertséget tekintve egyáltalán nem számít, hogy valaki melyik megyében vagy országrészben él, $\mathrm{s}$ annak sincs meghatározó szerepe, hogy budapesti vagy valamely szomszédos országból származik-e (20 és 35 pont közötti átlagok) (9. táblázat). A túlzottan Budapest-központú Magyarországon a megyékhez illetve régiókhoz való tartozásnál valamivel fontosabbnak tekintett fỏvárosi eredet meg- 
itélése még érthetö, de a szomszédos országból való származás indoklásakor már feltételezésekre vagyunk utalva. Valószínü, hogy a lakosság rejtett xenofóbiája fejezödik ki a határon túlról Magyarországra áttelepült magyarság helyzetét kedvezőnek tartó nézetben (ebben vélhetően az áttelepülteknek ténylegesen vagy feltételezetten juttatott kedvezmények játszanak szerepet). A megyék közötti eltérések szignifikánsak: a Bács-Kiskun megyében élök következetesen kevésbé vélik azt, hogy a régióban hozzájárul az elismeréshez, ha valaki valamilyen nagyobb területi egység lakója, míg a Békés megyeiek az átlagosnál nagyobb mértékben gondolják ezt.

\section{TÁBLÁZAT}

A régióban Ön szerint az egyes emberek elismerésében mennyire számít, hogy...* (How Much Do You Think the Recognition of an Individual in the Region Depends on...)

\begin{tabular}{lcccc}
\hline & Régió & $\begin{array}{c}\text { Bács- } \\
\text { Kiskun }\end{array}$ & Békés & Csongrád \\
\hline Fövárosi & 35 & 25 & 45 & 39 \\
Valamely szomszédos országból & 33 & 25 & 37 & 40 \\
származó & 25 & 17 & 38 & 23 \\
Dunántúli & 23 & 15 & 34 & 21 \\
Alföldi & 23 & 16 & 31 & 21 \\
Dél-alföldi & 22 & 14 & 30 & 23 \\
Csongrád megyei & 22 & 14 & 30 & 19 \\
Tiszántúli & 21 & 17 & 28 & 18 \\
Bács-Kiskun megyei & 20 & 12 & 32 & 18 \\
Békés megyei & & & & \\
\hline
\end{tabular}

*Százfokozatú skálára transzformált értékek: 0: egyáltalán nem, 100: sokat számít.

Forrás: Identitás-vizsgálat a Dél-Alföldi Régióban 1999.

A régióra vonatkozó, a nagyobb területi egységhez való tartozás alapján alkotott elismertség-típusok egyikében („regionális”) az alföldi és a tiszántúli származást, míg a másikban (,idegen”) - lényegesen alacsonyabb magyarázott varianciával - a dunántúli területhez, a fövároshoz illetve a szomszédos országok valamelyikéhez való tartozás együttes preferálását figyelhetjük meg. A Bács-Kiskun megyében élökre mindkét típus az átlagosnál kevésbé jellemző, viszont a Békés megyeiek a régió egészénél jobban preferálják a „regionális” elismertség-típust.

A lakóhelyi elismertséghez hasonlóan a megyei alminták regressziós modelljei szintén azt mutatják, hogy a szocio-kulturális jellemzők csak kismértékben magyarázzák a regionális szintre vonatkoztatott származási típusokat. A magyarázott variancia-hányadok azonban arra utalnak, hogy a tágabb földrajzi kategóriákhoz való tartozás (,idegen”) megítélésében mindegyik megyében nagyobb szerepe van a független változóknak. Bár a regionális elismertségnek a vallásosság vagy a felekezeti hovatartozás nem volt kritériuma, mégis figyelemre méltó, hogy az „idegen” típus esetében mind a három megyei modellnél a felekezet illetve a vallásosság egyike a szignifikáns magyarázó változóknak. További vizsgálatokat igényel az a feltételezésünk, hogy a nem a közvetlen környezethez tartozók befogadásában a 
vallásosságnak Békés és különösen Csongrád megyében inkább negatív, BácsKiskun megyében inkább pozitív hatása van.

\section{Elvárások - a régió és az Európai Unió}

A kutatás kérdőivében 15 olyan feladat értékelése is szerepelt, amely a szervezödő régió föbb tennivalói közé sorolható. A lakosság minden célt inkább jónak, mint rossznak vélt ( 50 pont feletti átlagok), leginkább a munkahelybővítő és az egészségügyi rendszer fejlesztésére vonatkozó célok prioritása a jellemző (65-65 pont). A megyék közötti szignifikáns eltérések arra utalnak, hogy Békésben a szakképzett fiatalok elhelyezkedését és a civil szerveződéseket kevésbé támogatják, mint más regionális fejlesztési célokat (10. táblázat).

\section{TÁBLÁZAT}

Kéjük, minösitse a régió fejlesztési céljait!*

(Please, Evaluate the Development Objectives of the Region)

\begin{tabular}{|c|c|c|c|c|}
\hline & Régió & $\begin{array}{l}\text { Bács- } \\
\text { Kiskun }\end{array}$ & Békés & Csongrád \\
\hline $\begin{array}{l}\text { Szakképzettséget szerzett fiatalok munka- } \\
\text { helyi megfelelésének elősegítése }\end{array}$ & 65 & 64 & 59 & 71 \\
\hline Egészségfejlesztő mozgalom támogatása & 65 & 63 & 64 & 67 \\
\hline $\begin{array}{l}\text { Regionális munkaerö-piaci információs } \\
\text { rendszer kialakítása }\end{array}$ & 63 & 63 & 59 & 67 \\
\hline Felnőttképzési szakemberek képzése & 63 & 63 & 63 & 64 \\
\hline $\begin{array}{l}\text { Helyi, kistérségi és regionális sajtó, televí- } \\
\text { zió, Internet honlap müködtetésének, hoz- } \\
\text { záférhetőségének támogatása }\end{array}$ & 60 & 60 & 60 & 60 \\
\hline $\begin{array}{l}\text { Az értelmiség és a gazdasági-politikai } \\
\text { menedzsment felkészítése az EU csatlako- } \\
\text { zással kapcsolatos feladatokra }\end{array}$ & 60 & 59 & 56 & 63 \\
\hline $\begin{array}{l}\text { Az Európai Unióval kapcsolatos ismeretek } \\
\text { társadalmasítása, elterjesztése }\end{array}$ & 60 & 60 & 57 & 62 \\
\hline A helyi közösségszerveződés elösegítése & 55 & 56 & 50 & 58 \\
\hline A tanyás térségek informatikai fejlesztése & 54 & 55 & 53 & 54 \\
\hline A távoktatás fejlesztése & 53 & 57 & 48 & 54 \\
\hline $\begin{array}{l}\text { A tanyás térségek szociális problémáinak } \\
\text { enyhítése tanyagondnok alkalmazásával }\end{array}$ & 53 & 58 & 49 & 53 \\
\hline „Többnyelvü régióért" program & 53 & 54 & 55 & 51 \\
\hline $\begin{array}{l}\text { Civil szervezetek támogatása, regionális } \\
\text { szervezödésük elősegítése }\end{array}$ & 51 & 57 & 48 & 50 \\
\hline $\begin{array}{l}\text { Határon túli magyarok, határainkon belüli } \\
\text { nemzetiségek és etnikumok anyanyelvi, } \\
\text { kulturális identitásának megőrzését, az } \\
\text { anyaországgal való kapcsolatok ápolását } \\
\text { segító program }\end{array}$ & 51 & 54 & 54 & 47 \\
\hline Távmunka végzés ösztönzése a régióban & 50 & 54 & 48 & 50 \\
\hline
\end{tabular}

*Százfokozatú skálára transzformált értékek: 0: nagyon rossz, 100: kiváló.

Forrás: Identitás-vizsgálat a Dél-Alföldi Régióban 1999. 
A célok bevonásával elvégzett fơkomponens-analízis két preferálási típust különített el (11. táblázat). A lényegesen nagyobb magyarázott varianciával bíró első típus - melynek az átlagosnál gyengébb támogatása Békés megyére jellemző - a munkaerö-piaci pozíciók javítását s ezzel együtt az informatikai fejlesztéseket helyezi elötérbe. A második típus sajátossága az uniós csatlakozás és a civil szervezódések együttes preferálása; ez egyedül Bács-Kiskun megyében erősebb a régió átlagánál.

\section{TÁBLÁZAT}

A régió fejlesztési céljainak preferálása alapján elkuilönitett típusok (Types Designated by the Preference of the Development Objectives of the Region)

\begin{tabular}{ll}
\hline \multicolumn{1}{c}{ „Munka és informatika” (51,1) } & „EU-csatlakozás és civil társadalom” $(8,5)$ \\
\hline Szakképzettséget szerzett fiatalok... & Többnyelvủ régióért program \\
Felnöttképzési szakemberek képzése & Az EU-val kapcsolatos ismeretek társadal- \\
& masítása \\
Egészségfejlesztő mozgalom & $\begin{array}{l}\text { Az értelmiség és a menedzsment felkészíté- } \\
\text { se az EU csatlakozásra }\end{array}$ \\
$\begin{array}{l}\text { Regionális munkaerö-piaci informá- } \\
\text { ciós rendszer... }\end{array}$ & $\begin{array}{l}\text { Határon túli és hazai kisebbségek identitá- } \\
\text { sának megórzése }\end{array}$ \\
$\begin{array}{l}\text { Távmunka végzés ösztönzése a } \\
\text { régióban }\end{array}$ & Civil szervezetek támogatása \\
$\begin{array}{l}\text { A távoktatás fejlesztése } \\
\text { Tanyás térségek informatikai } \\
\text { fejlesztése }\end{array}$ & A helyi közösségszerveződés elösegítése \\
Helyi tömegkommunikáció és & \\
Internet müködtetése & \\
\hline
\end{tabular}

Forrás: Identitás-vizsgálat a Dél-Alföldi Régióban 1999.

A Dél-Alföldi Régió központjának szerepére a három megye lakossága leginkább (53\%) Csongrád megye székhelyét, Szegedet tartja megfelelőnek. Lényegesen kisebb ugyan, de azért még jelentős a Kecskemétet $(27 \%)$ és Békéscsabát $(10 \%)$ említők aránya is. Saját megyeszékhelyükre leginkább a Csongrád (85\%) és a BácsKiskun megyeiek (57\%) voksoltak, míg a békésiek inkább Szegedet választották, mint Kecskemétet.

Szeged kiemelt preferálásában valószínúleg az is szerepet játszik, hogy a régióban élők véleménye szerint Csongrád megye rendelkezik a legjobb infrastrukturális és innovatív adottságokkal.

Napjaink hazai tömegkommunikációjának egyik állandó témája az ország Európai Uniós csatlakozása. A Dél-Alföldi Régió lakossága az ország EU-tagságának inkább hátrányait, mint elónyeit valószínúsíti, mivel elsősorban a meglévő szociális és területi egyenlötlenségek növekedésére számít. A lakosság nem füz reményeket sem a nyugdijasok, sem a pályakezdők helyzetének jobbra fordulásához, s nem hisz a vidék és a megyék országon belüli pozícióinak javulásában sem (50 pont alatti átlagpontok) (12. táblázat). 


\section{TÁBLÁZAT}

Véleménye szerint igazak vagy hamisak a következö állítások?*

(In Your Opinion, are the Following Statements True or False?

\begin{tabular}{|c|c|c|c|c|}
\hline $\begin{array}{c}\text { Ha Magyarország tagja lesz az } \\
\text { Európai Uniónak... }\end{array}$ & Régió & $\begin{array}{l}\text { Bács- } \\
\text { Kiskun }\end{array}$ & Békés & Csongrád \\
\hline $\begin{array}{l}\text { nagyobb lesz a különbség gazdagok } \\
\text { és szegények között }\end{array}$ & 71 & 68 & 79 & 68 \\
\hline $\begin{array}{l}\text { Budapest szerepe megnő az ország } \\
\text { életében }\end{array}$ & 70 & 66 & 74 & 68 \\
\hline $\begin{array}{l}\text { nagyobb lesz a különbség a keleti és } \\
\text { a nyugati országrész között }\end{array}$ & 60 & 58 & 66 & 58 \\
\hline $\begin{array}{l}\text { az egyes települések szerepe megnö } \\
\text { az ország életében }\end{array}$ & 57 & 58 & 61 & 53 \\
\hline $\begin{array}{l}\text { a régiók szerepe megnỏ az ország } \\
\text { életében }\end{array}$ & 50 & 52 & 47 & 50 \\
\hline a fiatalok helyzete javulni fog & 50 & 50 & 50 & 51 \\
\hline $\begin{array}{l}\text { összességében jobb lesz az ország } \\
\text { helyzete }\end{array}$ & 50 & 50 & 46 & 52 \\
\hline $\begin{array}{l}\text { a vidék szerepe megnő az ország } \\
\text { életében }\end{array}$ & 41 & 42 & 42 & 39 \\
\hline $\begin{array}{l}\text { a megyéknek nagyobb szerepe lesz } \\
\text { az ország életében }\end{array}$ & 37 & 36 & 39 & 36 \\
\hline a nyugdijasok helyzete javulni fog & 25 & 28 & 19 & 25 \\
\hline
\end{tabular}

*Az „igaz" válaszok százalékos aránya.

Forrás: Identitás-vizsgálat a Dél-Alföldi Régióban 1999.

Az EU-tagság néhány lehetséges következményét megfogalmazó változók bevonásával elvégzett főkomponens-analízis alapján a régió lakossága egy (nagyobb magyarázott varianciájú) „optimista” és egy „pesszimista” szcenárióra épülő véleménytípussal jellemezhetö. Az „optimista” típus elsősorban abban bízik, hogy az ország helyzete javulni fog, és a vidék szerepe fontosabbá válik, míg a „pesszimista" nézet képviselöi mindenekelött az egzisztenciális és területi különbségek növekedésével számolnak (13. táblázat).

$\mathrm{Az}$ „optimista” típus esetében nincs eltérés a megyei alminták score-átlagaitól, azonban az EU-tagsággal kapcsolatos pesszimista jövőképet a Békés megyében élők inkább elutasítják. Az EU-tagság megítélését a lakosság szocio-kulturális jellemzői egyik megyében sem befolyásolják lényegesen, de a regressziós modellek Békésben és Csongrádban igazolták a felsőfokú végzettség érték szerepét: a diploma valószínüsíti az Unióval kapcsolatos pesszimista elvárásokat, illetve az EUtagság optimista megítélésének elutasítását. 
Murányi István - Szoboszlai Zsolt :

Identitás-jellemzők a dél-alföldi régióban.

Tér és Társadalom, 14. 2000. 1. 27-49. p.

\section{TÁBLÁZAT}

Az EU-csatlakozás megitélése alapján elkülönitett típusok

(Types designated by the Evaluation of the EU-accession)

\begin{tabular}{|c|c|}
\hline „Optimista” $(28,5)$ & „Pesszimista” $(17,1)$ \\
\hline $\begin{array}{l}\text { Összességében jobb lesz az ország } \\
\text { helyzete }\end{array}$ & $\begin{array}{l}\text { Nagyobb lesz a különbség gazdagok és } \\
\text { szegények között }\end{array}$ \\
\hline $\begin{array}{l}\text { A vidék szerepe megnỏ az ország } \\
\text { életében }\end{array}$ & $\begin{array}{l}\text { Nagyobb lesz a különbség a keleti és a } \\
\text { nyugati országrész között }\end{array}$ \\
\hline A fiatalok helyzete javulni fog & $\begin{array}{l}\text { Megnő Budapest szerepe az ország } \\
\text { életében }\end{array}$ \\
\hline $\begin{array}{l}\text { A régiók szerepe megnő az ország } \\
\text { életében }\end{array}$ & $\begin{array}{l}\text { Az egyes települések szerepe megnő } \\
\text { az ország életében }\end{array}$ \\
\hline $\begin{array}{l}\text { A megyéknek nagyobb szerepe lesz az } \\
\text { ország életében }\end{array}$ & \\
\hline A nyugdíjasok helyzete javulni fog & \\
\hline
\end{tabular}

Forrás: Identitás-vizsgálat a Dél-Alföldi Régióban 1999.

\section{Jegyzetek}

${ }^{1} \mathrm{Az} 1200$ fös reprezentativ mintán végzett kutatás, valamint a dél-alföldi civil társadalom helyzetét elemzö vizsgálat részletes eredményeit az MTA Regionális Kutatások Központjában megjelenö Discussion Papers mühelytanulmány sorozat 32. köteteként, Gál Zoltán szerkesztésében megjelemỏ angol nyelvü publikáció tartalmazza. A patriotizmus (latin) eredeti jelentése hazaszeretet. A lokálpatriotizmus általános értelmezése: 1) Helyi érdekủ hazafiság; szükebb vidék (pl. lakóhely stb.) túlbecsülése, tủlhajtott szeretete. 2) A kisebb jelentőségủ helyi érdekeknek az országos ügyek elé helyezése (Bakos 1986).

3 A megyei alminták százalékos megoszlása: Bács-Kiskun megye: „sžik lokálpatrióta” $62 \%$, „tág lokálpatrióta” $38 \%$; Békés megye: „szilk lokálpatrióta” $58 \%$, „tág lokálpatrióta” $42 \%$; Csongrád megye: „szük lokálpatrióta" 54\%, „tág lokálpatrióta” $46 \%$.

\section{Irodalom}

A. Gergely A. (1996) Identitás és etnoregionalitás. Budapest, MTA PTI Etnoregionális Kutatóközpont.

Bakos F. (1986) Idegen szavak és kifejezések szótára. Budapest, Akadémiai Kiadó.

Bois, P. (1971) Taysans L'OUEST. Paris, Flammarion. 384. o.

Bőhm A.-Pál L. (szerk.) (1987) A helyi hatalom müködése. Budapest, MSZMP KB TTI.

Csatári B. (1989) A Tiszazug kistérségi problémái. Kutatási jelentés, kézirat. Kecskemét, MTA RKK Településkutató Csoport.

Csatári B. (1991) A falvak térkapcsolatai és fejlesztési lehetôségei, 1986-1990. Jász-Nagykun-Szolnok és Bács-Kiskun megyei vizsgálatok, kutatási jelentések. Kézirat. Kecskemét, MTA RKK ATI.

Csatári B. (1999) Az identitás földrajzi térelemei. Kézirat. MTA Stratégiai Kutatások. Pécs, MTA RKK.

Csepeli Gy. (1982) Nemzeti identitás és attitüd Magyarországon a 70-es években. Politikatudományi tanulmányok. - Polgár T. (szerk.), Budapest, Kossuth Könyvkiadó.

Csepeli Gy. (1992) Nemzet által homályosan. Budapest, Századvég.

Dessewffy T. (1996) A kedélyes labirintus. Multikulturalizmus és poszlkommunizmus. - Kritika. 12. 16-19. o.

Diez-Medrano, J. (1999) Imagined Europe: National Culture, Collective Memory, and Visions of European Integration in Germany, Great Britain, and Spain. American Sociological Association (ASA). Association paper.

Enyedi Gy. (1991) A lokalitás szerepe a modern társadalmakban. - Juss. 4.

Erös F. (szerk.) (1996) Azonosság és különbözöség. Budapest, Scientia Humana. 
Hamar A.-Murányi I.-Szoboszlai Zs. (1997) Az alföldi társadalom innovatív csoportjai. Alföld Kutatási Program II. Szolnok.

Hankiss E. (1983) Közơsségek válsága és hiánya. Társadalmi csapdák - Diagnózisok. Budapest, Magvetö Könyvkiadó.

Hargreaves, J. (1998) Ethno-Nationalist Movements in Europe: A Debate Nations and Nationalism. 4. 569-574. o.

Krappman, L. (1980) Az identitás szociológiai dimenziói. - Huszár T.-Léderer P. (szerk.), Budapest, Oktatási Minisztérium.

Lázár G. (1996) A felnött lakosság nemzeti identitása a kisebbségekhez való viszony tükrében. Többség kisebbség. Tanulmányok a nemzeti tudat témaköréböl. - Terestyéni T. (szerk.), Budapest, Osiris KiadóMTA-ELTE Kommunikációelméleti Kutatócsoport.

Murányi I.-Szoboszlai Zs. (1998) Ifjúsági életmód és szokásvizsgálat Jász-Nagykun-Szolnok megyében. Szolnok, MTA RKK ATI.

Murányi I.-Szoboszlai Zs. (1999) Sikeres városok, magasan, illetve alacsonyan fejlett települések az Alfóldön. Szolnok, MTA RKK ATI.

Muthien, Y.-Khosa, M. (1998) Constructing a Regional Political Identity in South Africa. - Social Identities. 3. 457-472. o.

Nánásiné Tóth É. (1996) Kötódések a városhoz. Kutatási jelentés. Kézirat. Kecskemét, MTA RKK ATI.

Pataki F. (1982) Az én és a társadalmi azonosságtudat. Budapest, Kossuth Könyvkiadó.

Robbins, T.J. (1999) Community and Place Identity Ambivalence. American Sociological Association. (ASA) Association paper.

Swarup, S. (1997) Regional and Religious Identities and Freedom: The Dilemmas of Plural Societies. Social Action. 3. July-Sept. 318-334. o.

Szabó I-OÖrkény A. (1998) Tizenévesek állampolgári kultúrája. Budapest, Minoritás Alapítvány.

Weakliem, D.L.-Biggert, R. (1999) Region and Political Opinion in the Contemporary United States. Social Forces. 3. 863-886. 0.

\section{CHARACTERISTICS OF THE IDENTITY IN THE SOUTH GREAT PLAIN}

\section{ISTVÁN MURÁNYI - ZSOLT SZOBOSZLAI}

This research was made relevant by the fact that the problems of identity became a focal point of the Hungarian social science research over recent years. Also, there are hardly any examples in Hungarian technical literature discussing the sociological or social geographical aspect of the identity organised by historical and geographical belonging.

In the study, local identity is considered as an organic part of the sense of social identity, on the basis of which the individual considers and believes him/herself a member of a social group which is wider than the personal contact network of the individual, and can be defined by a geographical category. During the research, the essential aspect was what categorisation (place of residence, micro-region, county, region) was the basis of the designation of the group, but it did not mean that spatial determination was exclusive. The basis of local identity in our opinion is those emotional and cognitive characteristics which define the belonging to the group described by the given categorisation, thus the belonging to a local or regional group also means the sense of identity with the traditions and value system of the group. 
The primary objective of the research was to explore which representations of the basic territorial categories of local and regional belongings (locality, micro-region, county, region) are present in the thinking of the people. During the exploration survey we thus concentrated on the comprehension of concepts in the first place, but we also dealt with the characterisation of the value systems, in addition to a few topical questions connected to regional development (organisation of the regions, EU accession etc.).

The most important findings of the survey carried out in the three counties of the South Great Plain (Bács-Kiskun, Békés and Csongrád), with an N $=1200$ sample, are as follows:

- For those who live in South Great Plain, the region and the micro-region are a geographical rather than a socio-historical concept.

- The most dominant element clinging to the region, besides the aesthetic environment and local patriotism, are relatives and friendships, while the least favourable are leisure time facilities and conditions of financial character. These also characterise the belonging to the county and the micro-region. Further analyses justified that the population of the three counties relates to the different levels of the living environment with the same feeling of identity.

- From among the assumed content criteria of local patriotism, in three (i.e. cultural, economic and social) cases, the comprehension of the concept by the population is mostly characterised by division, while in the fourth case a clear majority excludes the political activity or behaviour from the definition of the term. For the majority of the people, a local patriotism free from politics is rather of cultural, economic and social content.

- The relative majority of those capable of changing their place of residence would move to a settlement in Transdanubia, also, mentioned many times as potential destinations were the towns of the South Great Plain.

- The majority of those living in the region believe that the acknowledgement of the people in their own settlements mostly depends on the clinging to a settlement, a leading local position, school education and a firm financial background. In regional recognition it does not matter at all which county or part of Hungary one lives in, it is not definite, either, if somebody is from $\mathrm{Bu}$ dapest or from a neighbouring country.

- The people consider the most important task of the region the expansion of job opportunities and the implementation of development objectives relating to the improvement of the health care system.

- The population of the three counties thinks that the most suitable centre of the South Great Plain region is the seat of Csongrád county, Szeged.

- The population of the South Great Plain region is more concerned about the disadvantages rather than the advantages of the EU accession of Hungary, because they expect an increase in the existing social and territorial disparities. 